\title{
APPROACHES AND THEORIES TO THE STUDY OF POLITICAL SPEECH
}

\author{
Rafayel Harutyunyan* \\ Yerevan State University
}

The article considers political discourse as a global unit, attaching special significance to its linguistic characteristics that play an essential role in the formulation of political speech. The article reviews the theoretical background of the basic approaches and theories studying political speech and tries to outline their role in the context of the critical analysis of political discourse. The article also touches upon the main components of politics: language, action, conflict and cooperation, etc.

Keywords: politics, political speech, political discourse, text analysis, language-discourse correlation.

\section{Introduction}

In accordance with actual facts, our life is full of conflicts and, obviously, our planet is facing darker times which not only results from the political situation in different countries but also has its negative impact on it. Since the problem is worldwide, and politics has always been there side by side with the development of human civilization, political discourse is a subject for intensive interdisciplinary researches. It has a broad applicability and it seems essential to emphasize the role of this particular variety of discourse in shaping people's thoughts and attitudes, as some politicians make use of their rhetorical skills and experiences to change and control the people's mode of thought and will. Interestingly enough Charteris Black in his "Politicians and Rhetoric: The Persuasive Power of Metaphor" has the argumentation that the successful interlocutor, more specifically a politician must make serious attitudes and emotions that are already rooted in the listeners. As the author claims, understanding that their beliefs are

*rafayel.harutyunyan22@gmail.com

This work is licensed under a Creative Commons Attribution-NonCommercial 4.0 International License.
Received: 19.02 .2021

Revised: 20.04 .2021

Accepted: 28.05.2021

(C) The Author(s) 2021 
perceived, encouraged and supported, listeners start to connect to the policy. Followed by argumentations at an emotional level, the speaker - a politician seems to be morally correct. And to achieve this, a politician cannot solely use the lexical means of the language, the performance also plays an essential role. (Black, 2010, p.10 as cited in Kulo, 2009, p.3)

In this paper our main object of investigation is "politics" as a global phenomenon and approaches and theories to its study from a linguistic point of view. The present article is a part of a larger research aimed at figuring out an integrative study of media discourse where a special significance is attached to the political speeches in English. The criterion of the choice between those approaches and theories correlated and analyzed in this paper is based on the precondition of how the discussion of the mentioned approaches and theories contributes to the realization of our primary aim. The paper is an attempt to combine the already existing approaches to the study of political speech in order to highlight political language and political speech interconnection.

\section{The theoretical background of politics as a multilayered concept}

Emphasis on politics is considered to be historically and culturally determined and politics is meant to fulfill different functions due to different political activities. In this connection it should be noted that its careful examination and reconsideration can give us a chance to put knowledge to use in linguistics and provide with material for its clearer understanding.

To go over the problem a brief consideration of the term "politics" needs to be reconsidered. As the etymology reveals, it is derived from the Greek word "Polis", which means "city state". Alluding to Aristotle, one of the Greek philosophers, politics was a subject which dealt with all the activities and affairs of the city state. City state was inclusive, for Greeks made no distinction between the state and the government on the one hand, and state and society, on the other ("Politics", n.d.- a) In a loose sense, the dictionary meanings for the word "politics" vary greatly. Merriam-Webster dictionary defines it as an "art or science of government" as a first denotational meaning, as well as "the art or science concerned with guiding or influencing governmental policy". Definitions of "politics" unfold the meanings "political actions, practices, or policies", "the total complex of 
relations between people living in society" and "relations or conduct in a particular area of experience especially as seen or dealt with from a political point of view" ("Politics", n.d.-b).

As seen in the dictionary, the term "politics" could be a multifaceted unit like a double-edged sword, for it incorporates a number of clearly characterized implications that are clear and fair-minded such as "the art or science of government" and "political principles", but practically it carries a negative meaning too closely related to these "political activities characterized by artful and often dishonest practices" ("Politics", n.d.-b).

In accordance with Cambridge Dictionary, the word "politics" is connected with "someone's opinions about how a country should be governed", as well as "the activities of the government, members of lawmaking organizations, or people who try to influence the way a country is governed". ("Politics", n.d.-d)

Added to this, Oxford Dictionary defines "politics" as "the activities involved in getting and using power in public life, and being able to influence decisions that affect a country or a society" ("Politics", n.d.-c).

It can be assumed that the dictionary definitions are various, from simpler to complex and abstract ideas, and what is in common is the knowledge and science that create power and become an area where power can be applied. We tend to think that the most suitable definition for "politics" is the opinion and knowledge intertwined in one conceptual dimension because firstly it is the knowledge that shapes the opinion, and then this opinion is applied to formulate and bring into life this or that political action amongst both the ordinary citizens that share certain political viewpoints and politicians holding positions.

In practice, the linguistic study of politics and political speech has rather multifarious layers. It is studied from different perspectives: a social semiotic, cross-cultural, stylistic, as a form of rhetoric, text linguistics, discourse studies, critical discourse analysis, linguocultural and pragmatic, etc (Chlinton \& Ilyin, 1993; Chlinton \& Schaffner, 2002; de Landtsheer \& Feldman, 2000; Fairclough \& Woodak, 1997; Fairclough, 1995; Halliday, 1978; Kirvalidze, 2008; Kirvalidze, 2012; van Dijk, 1997, etc).

Since politics and political discourse have increasingly been in the center of linguistic investigations, it would be useful to introduce a brief 
review of the approaches and theories by different scholars which will help us to elucidate how political texts are produced, presented and perceived.

Andrew Heywood in his "Politics" defines the term as "the activity through which people make, preserve and amend the general rules under which they live, moreover, it is linked to the phenomena of conflict and cooperation (Heywood, 2013, p.2). For the author politics is exciting because people disagree, and above all it is a social activity, always a dialogue and never a monologue. The understanding of the phenomenon we come to from this point of view is that dialogic expressions always require more than one interlocutor and there are always questions and answers which can bring to endless conflicts depending on the context. In his approach to define politics he has taken into consideration the following basic features: politics as an arena and politics as a process. Accordingly, "politics" as an arena unfolds the definition of the "art of government and public affairs", while as a process it is described to be "compromise and consensus, power and the distribution of resources".

In their approach to define politics and political discourse N. Kirvalidze and N. Samnidze have stressed out the idea of understanding politics in its wide and narrow senses where the authors give prevalence to a narrow interpretation, i.e. they are in agreement with the decision of the van Dijkean interpretation of political discourse according to which it is a genre restricted to political reflections and has its thesaurus and specific functions, and it is important that political discourse take place in such institutional situations where the speaker expresses his/her point of view as a politician (van Dijk, 1998, 2002 as cited in Kirvalidze \& Samnidze, 2017, p.164).

Among other definitions we also share the point that "politics" is largely the language (Chlinton \& Schaffner, 2002). We accept this definition since we think that political thought and actions are indivisible from the political language because political speeches consist of words in a structural and conventional way, words that constitute political facts, therefore we cannot exclude political actions from the language. It should be added in this connection that politics is also defined as the language of mass media or any other institutions that are used in social and political spheres of communication. This observation can be seen in the work of "The Political Rhetoric of a United Europe" (Landtsheer, 1998, p.35). Referring to this definition we come to the firm belief that media as a discourse requires a 
special significance to the fact that it is the platform where the discourses, including political, encounter, and the illustrations of political events prevail in media representations. Hence, their languages coincide and share some similarities.

We have now to trace another approach of defining "politics" suggested by Adrian Beard in his work "The Language of Politics" (1999). What is interesting here to note is that the author attempts to give the definition of "politics" through the careful examination of the word "politician". Having central emphasis on the definition "practitioner" for the word "politician", the author tries to find a link between "politics" as an "art" and "politician" as a "practitioner", thus representing it in a good light irrespective of the dictionary definition "practitioner of the art of politics, essential to the working of human society but frequently despised by those outside the political arena". The author believes that a politician has important skills that are necessary for the "society" (Beard, 1999).

It is obvious that language and politics are inextricably interconnected, and language as a multifunctional, multidimensional and multilayered concept is the principal tool in the world of politics. For example, Paul Bayley in his "Analyzing language and politics" provides a reasonably objective criterion of how language, policy and law are linked to one another. Giving the examples of legislatures as forums for talk and text and constitutions as languages themselves, the author thinks that politics, although having non-linguistic goals is one of those institutional spheres of life in which language is constitutive of its actions, i.e., politics is conducted in and through talks and texts, and such talks and texts enact political action (Bayley, 2005). What we can infer from this viewpoint is that if those texts and talks precede real political actions, they condense much potential to be able to carry complex meanings. When analyzing these texts this factor should be taken into account.

Having made several allusions to the interconnection between language and politics, we shall shift to the discussion of discourse and language correlation.

In linguistics, discourse is regarded to be the main object of investigation in two sub-disciplines: conversation analysis and the analysis of written text. Discourse is predominantly seen in terms of the language above the sentence level and from the point of view of the language in 
general. It is believed that discourse is classified into four main categories which are exposition, narration, description and argument (Wodak, 2009, p.32).

Exposition basically centers on the type of discourse which makes the audience mindful of the subject of the discussion and definitions, and comparative analysis of different ideas and beliefs are examples of discourse exposition.

Narration is a form of discourse in which the means of communication is tales, mythology, or drama. Narrative discourse includes things like stage plays, stories, and folklore. This form entails representing something by the use of the senses.

Descriptive discourse enables the audience to develop a mental picture of what is being discussed, and the descriptive parts of novel or essay are descriptive discourse examples.

Argument as a category of discourse relies on valid logic and, through correct reasoning tries to motivate the audience. Examples of argumentative discourse include lectures, essays, and prose.

In the context of language and discourse correlation the classification of the types of discourse is vital for the careful examination of the language.

Discourse, according to van Dijk, is no longer limited to verbal text or conversation, but also includes the essence of situations as models of communicative events. Broad concepts like community, culture, mind, and language are often challenged by the meaning of discourse itself. (van Dijk, 2011, p.10). In the mentioned book, the author distinguishes between the following properties of discourse: discourse seen as part of social interaction, as power and domination, a form of communication, contextually situated, social semiosis, natural language use, complex, layered construct, sequences and hierarchies of text and talk, abstract structures vs. dynamic strategies. By saying social interaction, he intended to say that besides speaking and writing, language users engaged in talk or text accomplish social acts of many kinds and will do so by jointly and mutually coordinating their action.

Discourse is also viewed from the angle of power and domination. This property is relevant to public debate in particular, since power and power misuse, as well as dominance over public and social classes, can be described as a favorable entry into political life. 
Discourse is seen as a form of communication. We know that every form of text and talk has an informative function, and this is the way we come to know about knowledge, intentions, opinions and emotions of others. According to the author discourse as interaction and communication does not occur in a vacuum, but is, instead, a part of social situations of people's everyday lives and as an experience among others. Hence, it can be noted that discourse is contextually situated.

Discourse as social semiosis: According to the speaker, text and talk are more widely applied to other semiotic systems of sounds, images, gestures, and other embodied substantive social experiences than natural human languages.

Despite the above-mentioned concepts, the author continues to stress the significance of natural language usage, which is a remarkable human capacity to create and understand well-formed, meaningful combinations of words.

Discourse as a complex, layered construct: Dijk describes discourse as a multi-dimensional entity or phenomenon that integrates the three main dimensions of natural languages: form or expression, context, and action.

Sequences and hierarchies of text and talk: one of the crucial structural properties of text and talk is considered to be their sequentiality. The author is implying that every sequence of a system is conditioned by or perceived in relation to the previous ones and as planning the subsequent ones, thus defining the text's formal continuity, semantic and pragmatic coherence.

Abstract structures vs. dynamic strategies: The speaker means that discourse can also be studied as an entity made up of abstract structures, as a dynamic shifting sequence of events, or as strategically driven mental operations or social action steps.

It is clear that there is no single meaning for discourse, and drawing a clear line between meanings is becoming increasingly difficult. Furthermore, as a dynamic phenomenon, it is often characterized by linguistic and extralinguistic influences. If we view discourse from the angle of power, domination, control, and conflict we have to familiarize ourselves with some of the influence strategies. In order to describe and classify these strategies it is necessary to concentrate on the language politicians use, and as seen in theories, it is far from the truth. The use of language in political discourse is characterized with the employment of persuasive rhetoric, 
implied meanings, euphemisms, exclusion of references to undesirable reality, the use of language to arouse political emotions, etc. (Chlinton \& Schaffner, 2002, as cited in Petiy, 2020). As the author mentions, the influence function of the political language unfolds the following strategies: argumentation, manipulation, fascination, suggestion.

- Argumentation is accepted to be the method of precise thinking, the reason of which is the influence.

- Manipulation is linked to ethical purposes and uses language's referential and linguistic features.

- Fascination refers to the addressee's artistic motives and actualizes the language's aesthetic and emotional functions.

- Suggestion appeals to the recipient's mental thinking processes and recognizes the language's emotional role.

Considering these mentioned strategies and techniques we can observe that politicians intentionally use public speeches as an opportunity. Dependent on the occasion and the setting, politicians may be using their platform to make an impact on their targeted audience by their skillful rhetoric as well as assert their authority. Whatever the situation may be, such speakers take this opportunity to play to the crowd and attempt to chase them. Though, the target of the situation may be gaining votes or asserting their authority, however the goal, i.e., power always remains the same - to keep the people by their side. And it is not a secret that people are unwillingly attracted by those who have superiority and power to dominate. Finally, in order to attain the status of influential politicians, they are capable of processing the before-mentioned techniques and tactics thus manipulating people. In this connection, it will be important to remember the following types of manipulation when analyzing political speeches:

- Linguistic manipulation - including syntactic and grammatical, semantic and pragmatic techniques, etc.

- Non-linguistic manipulation - techniques which include charm and coercion tactics as well as other techniques such as rationalization, minimization, and diversion, etc. 


\section{Conclusion}

Summing up the results of the research we can state that politics is a multidimensional and multilayered discourse and therefore its definitions are diverse and complex. Politics directly or indirectly is connected with different spheres of life. In political discourse the speech can be processed for various purposes. Dependent on those purposes, the main tool, i.e., language, through which those purposes are realized, undergoes changes too. Depending on the nature of the political discourse the ways and means shaping the speech also change. If political communication is a pre-electoral campaign, political speaker, performing the function of persuasion or debate, employs the respective linguistic techniques and strategies to accomplish his/her purpose.

\section{References}

Bayley, P. (2005). Analyzing language and politics. Online Journal of Interdisciplinary Studies. Retrieved April 10, 2021, from https://www.academia.edu/855194/Analysing_language_and_politics Beard, A. (1999). The language of politics. Milton Park, England: Routledge.

Black, C. (2005). Politicians and rhetoric: The persuasive power of metaphor. London, Palgrave: Macmillan.

Chlinton, P., \& Schaffner, Ch. (2002). Politics as text and talk: Analytic approaches to political discourse. Amsterdam: John Benjamins Publishing Company.

Chlinton, P. (1993). Metaphor in political discourse: the case of the

'Common European House'. Discourse \& Society. 4 (1), 7-31. https://doi:10.1177/0957926593004001002

de Landtsheer, Ch. (1998 a). The political rhetoric of a United Europe. In: Feldman, O., \& de Landtsheer. Ch. Politically speaking: a worldwide examination of language used in public sphere. New York: Praeger.

de Landtsheer, Ch., \& Feldman, O. (2000). Beyond speech and symbols:

Explorations in the rhetoric of politicians and the media. Westport: Praeger.

Fairclough, N. (1995). Critical discourse analysis. London: Longman. 
Fairclough, N., Mulderrig, J., \& Wodak, R. (2011). Critical discourse analysis. In T.A. van Dijk (Ed.). Discourse studies: A multidisciplinary introduction. SAGE Publications Ltd, 357-378. https://www.doi.org/10.4135/9781446289068.n17

Halliday, M.A.K. (1978). Language as a social semiotic: The social interpretation of language and meaning. London: Edward Arnold.

Heywood, A. (2013). Politics. London: Red Globe Press.

Kirvalidze, N. (2008). A university course in text linguistics. Tbilisi: Ilia Chavchavadze State University Press.

Kirvalidze, N. (2012). Linguocultural and pragmatic fundamentals of teaching political discourse at higher school. Proceedings of ICERI2012 - 5th International Conference of Education, Research and Innovation, 5171-5176. Retrieved from https://library.iated.org/view/KIRVALIDZE2012LIN

Kirvalidze, N., \& Samnidze, N. (2016). Political discourse as a subject of interdisciplinary studies. Journal of Teaching and Education. 05 (01), 161-170. Retrieved from https://www.researchgate.net

Kulo, L. (2009). Linguistic features in political speeches. (Bachelor thesis, Luleå University of Technology, Luleå, Sweden). Retrieved March 20, 2021, from http://www.diva-portal.org/smash/get/diva2:1028973/FULLTEXT01.pdf

Petiy, N. (2020). Linguistic influence in political discourse. Збірник наукових праць, $\Lambda^{\prime} \mathrm{O} Г \mathrm{O} \Sigma, 81-83$. https://doi.org/10.36074/26.06.2020.v2.31

van Dijk, T. (1997). Discourse studies: a multidisciplinary introduction. London: SAGE Publications Ltd.

van Dijk, T. (1998). What is political discourse analysis? In J. Blommaert, \& C. Bulcaen (Eds.). Political Linguistics, Belgian journal of linguistics, volume 11, Issue 1, 11-52, https://doi.org/10.1075/bj1.11.03dij.

van Dijk, T. (2002). Political discourse and political cognition. In P. Chlinton, \& C. Schaffner (Eds.). Politics as text and talk: analytic approaches to political discourse, 203-237, https://doi.org/10.1075/dapsac.4.11dij

van Dijk, T. (2011). Discourse studies: A multidisciplinary introduction. New York: SAGE Publications Ltd. 
Wodak, R. (2009). The discourse of politics in action. London Palgrave: Macmillan.

\section{Dictionaries and Encyclopedias}

Politics. (n.d.-a). In Encyclopedia Britannica. Retrieved from https://britannica.com

Politics. (n.d.-b). In Merriam Webster Dictionary. Retrieved from https://merriam-webster.com

Politics. (n.d.-c). In Oxford Learner's Dictionary. Retrieved from www.oxfordlearnersdictionaries.com/

Politics. (n.d.-d). In Cambridge Dictionary. Retrieved from https://dictionary.cambridge.org

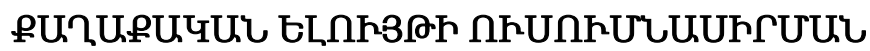

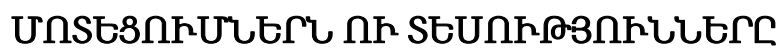

\section{nuwqujt L Zupnıpjnı\{jui}

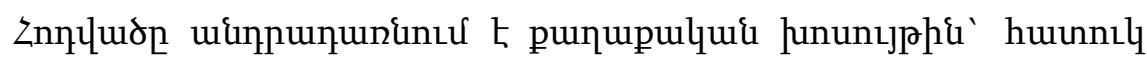

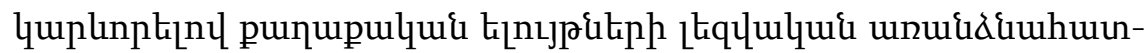

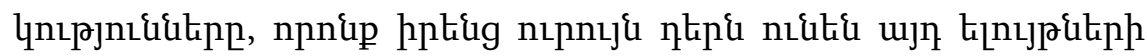

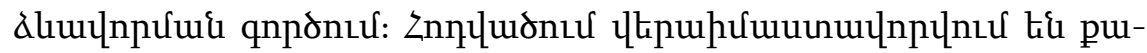

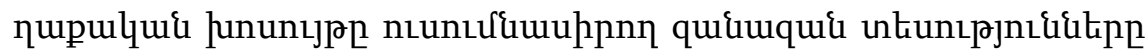

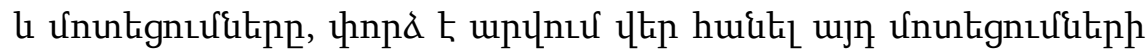

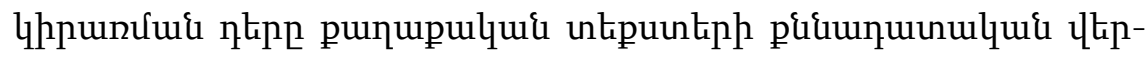

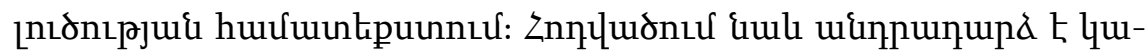

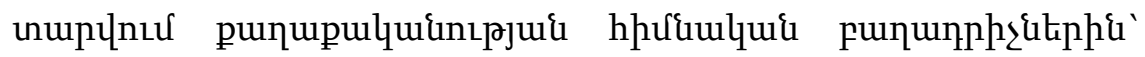

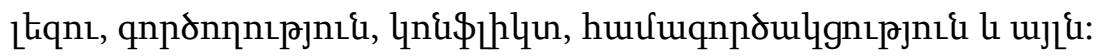

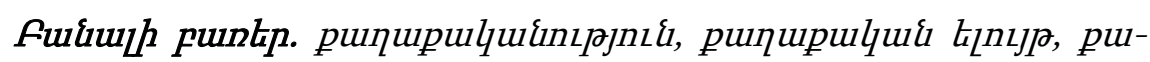

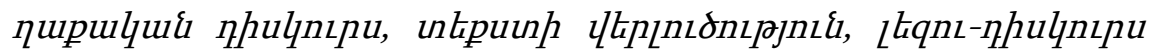

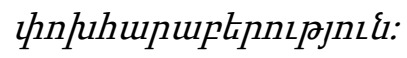

